Andrei A. Orlov

Milwaukee, Wisconsin, USA

\title{
THE FACE AS THE HEAVENLY COUNTERPART OF THE VISIONARY IN THE SLAVONIC LADDER OF JACOB
}

\section{Introduction}

The book of Genesis portrays Jacob as someone who not only saw God but also wrestled with Him. Jacob's visionary experiences begin in Genesis 28 where he sees in a dream the ladder on which the angels of God are ascending and descending. Above the ladder Jacob beholds the Lord. The distinct feature of the Bethel account is the paucity of theophanic imagery. Despite the fact that the vision is linked with the celestial realm («ladder's top reaching to heaven»), which is labeled in the story as «the awesome place», «the house of God», and «the gate of heaven», the narrative does not offer any descriptions of God's celestial court or his appearance. Instead we have the audible revelation of God, his lengthy address to Jacob with promises and blessings.

God appears again to Jacob in Genesis 32. While the narrative stresses the importance of the vision of God (the account claims that Jacob «saw God face to face» and even called the place of wrestling Peniel/Penuel — «The Face of God»), it focuses its description on Jacob's wrestling with God rather than his seeing of God.

The reference to the motif of God's Face (which plays an important role in a number of biblical theophanic accounts) ${ }^{1}$ and to Jacob's seeing of God «face to face» could however indicate that the authors or editors of Jacob's account might be cognizant of the broader anthropomorphic theophanic debates in which the motif of God's Face ${ }^{2}$ played an important role. In order to

${ }^{1}$ See, e.g., Exod. 33:18-23; Ps. 17:15.

${ }^{2}$ On the Face of God, see S. Balentine, The Hidden God: The Hiding Face of God in the Old Testament (Oxford, 1983) 49-65; A. DE Conick, Heavenly Temple Traditions and Valentinian Worship: A Case for First Century Christology in the Second Century // The Jewish Roots of Christological Monotheism / Ed. C. C. Newman, J. R. Davila, G. S. Lewis (Leiden, 1999) (JSJ, 63) 325-330; W. Eichrodt, Theology of the Old Testament. 2 vols (Philadelphia, 1967) Vol. 2. 35-39; M. Fishbane, Form and Reformulation of the Biblical Priestly Blessing // JAOS 103 (1983) 115-121; S. Olyan, A Thousand Thousands Served Him: Exegesis and the Naming of Angels in Ancient Judaism (Tübingen, 1993) (TSAJ, 36) 105-109; J. REINDL, Das Angesicht Gottes im Sprachgebrauch des Alten Testaments (Leipzig, 1970) (ETS, 25) 236-237; 
clarify these theophanic developments, which can shed further light on the background of Jacob's biblical story, the current research must turn to other materials associated with Jacob's traditions where his visionary accounts have a more elaborated form. Such materials include the Ladder of Jacob, ${ }^{3}$ a Jewish pseudepigraphon, which has survived in its Slavonic translation.

\section{The Slavonic Account of Jacob's Vision}

The materials known under the title the Ladder of Jacob, have been preserved solely in Slavonic as a part of the so-called Толковая Палея ${ }^{4}$ (the Explanatory Palaia) where the editors of its various versions reworked ${ }^{5}$ and

M. SмIтH, «Seeing God» in the Psalms: The Background to the Beatific Vision in the Hebrew Bible // CBQ 50 (1988) 171-183.

${ }^{3}$ On the Ladder of Jacob, see H. F. Sparks (ed.), The Apocryphal Old Testament (Oxford, 1984) 453-463; N. BonweTsch, Die Apokryphe «Leiter Jakobs» // Göttinger Nachrichten, philol.-histor. Klasse (1900) 76-87; E. BRATKE, Das sogenannte Religionsgespräch am Hof der Sasaniden (Leipzig, 1899) (ТU, 4.3) 101-106; И. ФРАНко, Апокріфи і легенди з українських рукописів (Monumenta Linguae Necnon Litterarum Ukraino-Russicarum [Ruthenicarum]) 5 тт. (Львов, 1896-1910) T. 1. 108120 ; А. И. ЯцимиРский, Библіографический обзоръ апокрифовъ въ южнославянской и русской письменности (Списки Памятников). Вып. 1. Апокрифы ветхозаветные (Петроград, 1921) 38-39; M. R. JAMES, Ladder of Jacob // IDEM, The Lost Apocrypha of the Old Testament (London, 1920) (TED, 14) 96-103; J. KugEL, The Ladder of Jacob // HTR 88 (1995) 209-227; Н. М. Вторых, Древности. Труды Славянской комиссии Московского археологического общества, 2 (1902) Протокол 1; Г. КушелЕв-БЕзБоРодко, Памятники старинной русской литературы. 4 тт. (Санкт-Петербург, 1865) Т. 3. 27-32; Палея толковая по списку, сделанному в г. Коломне в 1406 г. / Труд учеников Н. С. Тихонравова (Москва, 1892) 153-166; И. Я. ПорфиРьЕВ, Апокрифические сказания о ветхозаветных лицах и событиях по рукописям соловецкой библиотеки // Сборник отд. русского языка и словесности 17.1 (Санкт-Петербург, 1877) 138-149; М. А. САлминА, Лествица Иакова // Словарь книжников и книжности Древней Руси (XI - первая половина XIV в.) / Под ред. Д. С. ЛихАчевА (Ленинград, 1987) 230-231; Д. Святский, Лестница Иакова или сон наяву (Санкт-Петербург, 1911) 31-32; Н. С. Тихонравов, Памятники отреченной русской литературы. 2 тт. (Санкт-Петербург, 1863) Т. 1. 91-95; Толковая палея 1477 года (Санкт-Петербург, 1892) (Общество любителей древнерусской письменности, 93) 100a-107b.

${ }^{4}$ On Толковая Палея, see В. АдриАновА, К литературной истории Толковой Палеи (Киев, 1910); В. М. Истрин, Редакции Толковой Палеи // ИОРЯС 10/4 (1905) 150-151; Палея толковая по списку, сделанному в г. Коломне...; ПоРФиРьЕв, Апокрифические сказания... 11-12; Толковая палея 1477 года...; О. В. Творогов, Палея Толковая // Словарь книжников и книжности Древней Руси... 285-288; В. М. Успенский, Толковая Палея (Казань, 1876).

${ }^{5}$ Lunt observes that the seventh chapter of the Ladder is a later Christian addition juxtaposed to the story by a Slavic (possibly, Russian) editor of Palaia; see H. G. LunT, Ladder of Jacob // OTP. Vol. 2. 401-411 (404-405). 
rearranged them. Despite its long life inside the compendium of heterogeneous materials and its long history of transmission in Greek and Slavonic milieux, the pseudepigraphon seems to have preserved several early traditions that can safely be placed within the Jewish environment of the first century CE. Scholars propose that the Slavonic Ladder of Jacob is most likely derived from its Greek variant, which in turn appears to have been translated from Hebrew or Aramaic. ${ }^{6}$ The content of the work is connected with Jacob's dream about the ladder and the interpretation of the vision. In Horace Lunt's translation, the text is divided into seven chapters. ${ }^{7}$ The first chapter depicts Jacob's dream in which he sees the ladder and receives God's audible revelation about the promised land and blessings upon his descendants. In the second chapter, a reader encounters Jacob's lengthy prayer to God in which he uncovers additional details of his dream and asks God to help him interpret the dream. In chapter 3, God sends to Jacob the angel Sariel as an interpreter. In chapter 4, Sariel informs Jacob that his name has been changed to Israel. Perceptive readers may thus notice that despite the title of pseudepigraphon, its text is not only confined to the ladder account but also accommodates features of Jacob's other visions, namely, the substitution of his name during the wrestling account. The last three chapters of the Ladder recount Sariel's eschatological interpretations of Jacob's dream in which he reveals to the visionary the details of future human history.

\section{The Face as God's Kavod}

The imagery of the divine/angelic faces plays a prominent role in the first chapter of Ladder. The text describes Jacob's dream in which he sees a twelve step ladder, fixed on the earth, whose top reaches to heaven with the angels ascending and descending on it. This familiar biblical motif then is elaborated further and adds some new features. ${ }^{8}$ The story relates that on the ladder

${ }^{6}$ Kugel, The Ladder of Jacob... 209.

${ }^{7}$ In this paper I have used H. Lunt's English translation of Ladder and follow his division of chapters and verses; see LuNT, Ladder of Jacob... 401-411. The Slavonic citations are drawn from the following publications of the manuscripts: Recension A — MS S (Sinodal'naja Palaia. Sin. 210) published in Толковая Палея 1477 года... 100a-107b; MS R (Rumjancevskaja Palaia. Rum. 455) published in КушелЕв-БЕзБородко, Памятники старинной русской литературы... Т. 2. 27-32; MS F (Krehivskaja Palaia) published in ФРАнко, Апокріфи і легенди... Т. 1. 108-120; Recension B - MS K (Kolomenskaja Palaia. Tr.-Serg. 38) published in ТихонРАвов, Памятники отреченной русской литературы... Т. 1. 91-95 and in Палея толковая по списку, сделанному в г. Коломне... 153-166; MS P (Soloveckaja Palaia. Sol. 653) published in ПорфиРьЕв, Апокрифические сказания... 138-149.

${ }^{8}$ Ladder of Jacob 1.3-10 reads: «And behold, a ladder was fixed on the earth, whose top reaches to heaven. And the top of the ladder was the face as of a man, carved out of fire. There were twelve steps leading to the top of the ladder, and on 
Jacob sees twenty-two human faces with their chests, two of them on each step of the ladder. On the top of the ladder, he also beholds another human face «carved out of fire» ${ }^{9}$ with its shoulders and arms. In comparison with the previous «faces», this fiery «higher» face looks «exceedingly terrifying». The text portrays God standing above this «highest» face and calling Jacob by his name. The depiction leaves the impression that God's voice ${ }^{10}$ is hidden behind this fiery terrifying «face» as a distinct divine manifestation, behind which God conveys to Jacob his audible revelation about the Promised Land and the blessings upon Jacob's descendants.

This description of the celestial «Face» as the fiery anthropomorphic extent, ${ }^{11}$ which serves as the embodiment of the deity leads us to another Slavonic text in which the theme of the fiery Face looms large. This text is 2 (Slavonic) Enoch, a Jewish apocalypse, the hypothetical date of which (c. first century CE) is in close proximity to the date of Ladder. 2 Enoch $22^{12}$ contains a theophanic depiction of the Face of the Lord, which emits light and fire. The important detail that connects this passage with Ladder is that the Face in 2 Enoch is similarly defined as «fiery» ${ }^{13}$ and «terrify-

each step to the top there were two human faces, on the right and on the left, twentyfour faces (or busts) including their chests. And the face in the middle was higher than all that I saw, the one of fire, including the shoulders and arms, exceedingly terrifying, more than those twenty-four faces. And while I was still looking at it, behold, angels of God ascended and descended on it. And God was standing above its highest face, and he called to me from there, saying, "Jacob, Jacob!" And I said, "Here I am, Lord!" And he said to me, "The land on which you are sleeping, to you will I give it, and to your seed after you. And I will multiply your seed...”». LuNT, Ladder of Jacob... 407.

${ }^{9}$ Ibid. 406.

${ }^{10}$ James Charlesworth notes that in the Ladder, as «in some of other pseudepigrapha, the voice has ceased to be something heard and has become a hypostatic creature». See Charlesworth's comment in LunT, Ladder of Jacob... 406.

${ }^{11}$ I use the term «extent» since the Ladder specifically mentions shoulders and arms in its description of the Face.

${ }^{12} 2$ En. 22.1-4 (the longer recension): «I saw the view of the face of the Lord, like iron made burning hot in a fire and brought out, and it emits sparks and is incandescent. Thus even I saw the face of the Lord. But the face of the Lord is not to be talked about, it is so very marvelous and supremely awesome and supremely frightening. And who am I to give an account of the incomprehensible being of the Lord, and of his face, so extremely strange and indescribable? And how many are his commands, and his multiple voice, and the Lord's throne, supremely great and not made by hands, and the choir stalls all around him, the cherubim and the seraphim armies, and their neversilent singing. Who can give an account of his beautiful appearance, never changing and indescribable, and his great glory? And I fell down flat and did obeisance to the Lord». F. ANDERSEn, 2 (Slavonic Apocalypse of) Enoch // OTP. Vol. 1. 136.

${ }^{13} \mathrm{~F}$. Andersen in his commentary on $2 \mathrm{En} .22$ notes the similarities between the fiery face in 2 Enoch and the face of fire in Ladder. Cf. ANDERSEn, 2 Enoch... 137, n. 22d. 
ing». ${ }^{14}$ Another parallel is that in both 2 Enoch and Ladder the Face is understood as the luminous representation of the deity, behind which $\mathrm{He}$ can convey His audible revelation to visionaries. ${ }^{15}$

It is noteworthy that the incandescent Face in 2 Enoch, as well as in Lad$d e r$, is depicted not as a part of an angelic or divine «body» but rather as the fiery «forefront» of the whole anthropomorphic extent. ${ }^{16}$

It has been previously noted ${ }^{17}$ that this fiery extent, labeled in some biblical and intertestamental texts as the «Face», is related to the glorious celestial entity known in theophanic traditions as God's Kavod..$^{18}$ In these traditions, the Face often serves to designate the radiant façade of the divine Kavod. ${ }^{19}$ This tendency to equate the Face with the Kavod can be found already in some biblical accounts, including Exod. 33:18-23, where in response to Moses' plea to God to show him his glory, God answers that it is impossible for a human being to see God's face. ${ }^{20}$

${ }^{14}$ Both Slavonic pseudepigraphons in their description of the Face share the similar Slavonic terminology, words like face (пице); fiery (огNеNa, изь огNA); terrifying (страшмо). Cf. ФРАНКО, АПокріфи і легенди... Т. 1. 109; КУШЕЛЕВ-БЕзБоРодКО, Памятники старинной русской литературы... Т. 3. 27; ПоРфиРьЕВ, Апокрифические сказания... 138; ТихонРАвов, Памятники отреченной русской литературы... T. 1. 91; Толковая палея 1477 года... 100b; A. VAILlant, Le Livre des secrets d'Hénoch: Texte slave et traduction française (Paris, 1976 [1952]) (Textes publiés par l'Institut d'études slaves, 4) 24 and 38.

${ }^{15}$ See A. De Conick, Seek to See Him: Ascent and Vision Mysticism in the Gospel of Thomas (Leiden, 1996) (SVC, 33) 104-105.

${ }^{16}$ It is notable that although the Ladder uses the Slavonic term lice («face») in its depiction of the «Face», the text mentions that the face Jacob sees has also shoulders and arms.

${ }^{17}$ A. Orlov, Ex 33 on God's Face: A Lesson from the Enochic Tradition // Society of Biblical Literature 2000 Seminar Papers (Atlanta, 2000) (SBLSP, 39) 130147.

${ }^{18}$ The early traces of this tendency to identify Kavod with the Face within Enochic tradition can be seen already in the Book of the Watchers 14 where the enthroned Glory is labeled the Face. Cf. 1 En. 14:21: "And no angel could enter, and at the appearance of the face (gașs) of him who is honored and praised no (creature of) flesh could look» (M. A. KNIBB, The Ethiopic Book of Enoch: A New Edition in the Light of the Aramaic Dead Sea Fragments. 2 vols (Oxford, 1978) Vol. 2. 99).

${ }^{19}$ It is noteworthy, that already in the classic Ezekilean description of God's Glory in Ezek. 1:27, Kavod is described similarly to the description of the Face in Ladder, namely, as the fiery bust: «I saw that from what appeared to be his waist up he looked like glowing metal, as it full of fire, and that from there down he looked like fire; and brilliant light surrounded him».

${ }^{20}$ See Exod. 33:18-23: «Then Moses said, "Now show me your glory (ברדך)". And the Lord said, "I will cause all my goodness to pass in front of you, and I will proclaim my name, the Lord, in your presence... but", he said, "you cannot see my face ("פ), for no one may see me and live"». 
The second chapter of the Ladder, in which the visionary asks God to interpret the dream, provides several additional important details about the dream that explicitly identify the fiery Face with God's Kavod.

In the second chapter of the Slavonic text, Jacob offers a prayer in which he discloses further details of his vision of the Face. Ladder 2:7-19 reads:

Lord God of Adam your creature and Lord God of Abraham and Isaac my fathers and of all who have walked before you in justice! You who sit firmly on the cherubim and the fiery throne of glory... and the many-eyed (ones) just I saw in my dream, holding the four-faced cherubim, bearing also the many-eyed seraphim, carrying the whole world under your arm, yet not being borne by anyone; you who have made the skies firm for the glory of your name, stretching out on two heavenly clouds the heaven which gleams under you, that beneath it you may cause the sun to course and conceal it during the night so that it might not seem a god; (you) who made on them a way for the moon and the stars; and you make the moon wax and wane, and destine the stars to pass on so that they too might not seem gods. Before the face of your glory the six-winged seraphim are afraid, and they cover their feet and faces with their wings, while flying with their other (wings), and they sing unceasingly a hymn: ...whom I now in sanctifying a new (song)... Twelve-topped, twelve-faced, many-named, fiery one! Lightning-eyed holy one! Holy, Holy, Holy, Yao, Yaova, Yaoil, Yao, Kados, Chavod, Savaoth... ${ }^{21}$

Several details are important in this description. Jacob's prayer reveals that his dream about the Face might represent the vision of the Throne of God's Glory. A number of points need to be noted to support this conclusion:

a. The prayer refers to «his many-eyed ones», Wheels, the special class of the Angels of the Throne who are described in Ezek. 1:18 as the angelic beings «full of eyes».

b. The text describes the deity as seated on the fiery Throne of Glory.

c. The vision contains references to the angelic liturgy and the Trisagion.

d. The text refers to the fear of the angelic hosts, who stand in the front of the terrifying fiery «Face» and try to protect themselves with their wings («before the face of your glory the six-winged seraphim are afraid, and they cover their feet and faces with their wings»). The motif of protection against the harmful brilliance of God's Throne is typical to theophanic descriptions of Kavod from the earliest accounts found in Isa. 6:1-4 to the latest accounts found in 3 Enoch, which relate that «...in 'Arabot there are 660 thousands of myriads of glorious angels, hewn out of flaming fire, standing opposite the throne of glory. The glorious King covers his face,

\footnotetext{
${ }^{21}$ LunT, Ladder of Jacob... 408.

${ }^{22}$ Andersen, 2 Enoch... 137.
} 
otherwise the heaven of 'Arabot would burst open in the middle, because of the glorious brilliance». ${ }^{23}$

e. The passage also contains a specific terminology associated with the Throne imagery. It has been mentioned earlier that the Slavonic text of the Ladder is possibly based on the Semitic original. Ladder of Jacob 2.18 contains a non-Slavonic word Chavod ${ }^{24}$ which the translator (H. Lunt) defines as the transliterated Hebrew term Kavod. ${ }^{25}$

f. Finally, the passage explicitly identifies the fiery Face with God's glory. Ladder of Jacob 2:15 says that «before the face of your glory the sixwinged seraphim are afraid...». Thus the fiery face in Ladder 1:6 is not just any face but the Face of God.

The apparent similarities between two Slavonic accounts indicate that Ladder, as well as 2 Enoch, seem to represent a single tradition in which the fiery Face is associated with Kavod.

Additional evidence to support the view that the fiery Face on the ladder in Ladder represents God's Kavod can be found in the targumic accounts of Jacob's story. Targum Pseudo-Jonathan and Targum Onqelos give numerous references to the Glory of the Lord in their description of Jacob's vision of the ladder.

Targum Pseudo-Jonathan to Gen. 28:13-17 reads:

And, behold, the Glory of the Lord (יקרא דה") stood beside him and said to him, «I am the Lord, the God of your father Abraham and the God of Isaac. The land on which you are lying I will give to you and to your children»... And Jacob awoke from his sleep and said, «In truth the Glory of the Shekinah (יקר שכינתא) of the Lord dwells in this place, and I did not know it». He was afraid and said, «How awesome and glorious is this place! This is not a profane place, but a sanctuary to the name of the Lord; and this is (a place) suitable for prayer, corresponding to the gate of heaven, founded beneath the Throne of Glory (כורסי יקרא).26.

Targum Onqelos ${ }^{27}$ to Gen. 28:13-16 also reflects the same tradition, which depicts Jacob's encounter as the vision of the Divine Glory. In both targumic

${ }^{23}$ P. AleXAnder, 3 (Hebrew Apocalypse of) Enoch // OTP. Vol. 1. 223-315 (305).

${ }^{24}$ MS $S$ - Chavod; MS $R$ - Chavod; MS F-Chsavod. Seе Толковая палея 1477 года... 101b; КушЕЛЕВ-БЕзБОРодко, Памятники старинной русской литературы... Т. 1. 110.

${ }^{25}$ See LunT, Ladder of Jacob... 408, n. 2.i.

${ }^{26}$ Targum Pseudo-Jonathan: Genesis / Trans. M. MAHER (Collegeville, MN, 1992) (AB, 1B) 99-100; Biblia Polyglotta Matritensia. IV. Targum Palaestinense in Pentateuchum. 5 vols / Ed. A. Díez Macho (Matriti, 1977) Vol. 1. 195-197.

${ }^{27}$ «....and here, The Glory of the Lord ("יי" said, "I am the Lord, the God of your Father Abraham and the God of Isaac: the land 
accounts, the Glory of the Lord seems topologically located in the place which in Ladder is occupied by the Face.

\section{The Face as Jacob's Heavenly Counterpart}

Scholars have previously noted that in Ladder the fiery Face not only embodies God's Glory but also seems to represent the heavenly counterpart of Jacob. ${ }^{28}$ They observe that the bust of fire, labeled in Ladder as the Face, can be associated with the heavenly «image» of Jacob engraved on the Throne of Glory. ${ }^{29}$ The traditions about the heavenly «image» of Jacob are present in several targumic ${ }^{30}$ texts, ${ }^{31}$ including Targum Pseudo-Jonathan, Targum Neofiti $^{32}$ and the Fragmentary Targum. ${ }^{33}$

on which you sleep I will give to you and to your offspring...”. The Jacob awoke from his sleep and said, "Truly the Glory of the Lord ("קרי" "י") dwells in this place, and I did not know it" ( (The Targum Onqelos to Genesis / Trans. B. Grossfeld (Wilmington, DE, 1988) (Aramaic Bible, 6) 104; M. Aberbach, B. Grossfeld [eds.], Targum Onkelos to Genesis: A Critical Analysis Together with an English Translation of the Text (New York, 1982) 171).

${ }^{28}$ J. Fossum, The Image of the Invisible God (Freiburg - Göttingen, 1995) (NTOA, 30) $135-151$ (143).

${ }^{29}$ «... [in the Ladder] in the fiery bust of the terrifying man we are probably correct to see the heavenly 'image' of Jacob» (Fossum, The Image of the Invisible God... 143, n. 30).

${ }^{30}$ The same tradition can be found in rabbinic texts. Gen. $R$. 68:12 reads: «...thus it says, Israel in whom I will be glorified (Isa. xlix, 3); it is thou, [said the angels, ] whose features are engraved on high; they ascended on high and saw his features and they descended below and found him sleeping». (Midrash Rabbah. 10 vols. (London, 1961) Vol. 2. 626). On Jacob's image on the Throne of Glory, see also Gen. R. 78:3; 82:2; Num. R. 4:1; b. Hul. 91b; PRE. 35.

${ }^{31}$ On the traditions about Jacob's image engraved on the Throne see E. R. WoLfson, Along the Path: Studies in Kabbalistic Myth, Symbolism, and Hermeneutics (Albany, NY, 1995) 1-62, 111-186.

32 «And he dreamed, and behold, a ladder was fixed on the earth and its head reached to the height of the heavens; and behold, the angels that had accompanied him from the house of his father ascended to bear good tidings to the angels on high, saying: "Come and see the pious man whose image is engraved in the throne of Glory, whom you desired to see». And behold, the angels from before the Lord ascended and descended and observed him» (Targum Neofiti 1: Genesis / Trans. M. MCNAMARA (Collegeville, MN, 1992) (Aramaic Bible, 1A) 140).

33 «...And he dreamt that there was a ladder set on the ground, whose top reached towards the heavens; and behold the angels that had accompanied him from his father's house ascended to announce to the angels of the heights: "Come and see the pious man, whose image is fixed to the throne of glory..."». (M. L. KLEIN, The Fragment-Targums of the Pentateuch According to Their Extant Sources. 2 vols. (Rome, 1980) (AB, 76) Vol. 1. 57; Vol. 2. 20). 
In Targ. Ps.-J. to Gen 28.12 the following description can be found:

$\mathrm{He}$ [Jacob] had a dream, and behold, a ladder was fixed in the earth with its top reaching toward the heavens ... and on that day they (angels) ascended to the heavens on high, and said, Come and see Jacob the pious, whose

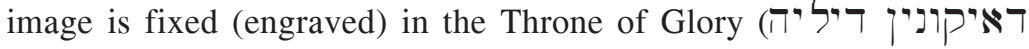
קביעא בכורסי יקרא (קx), and whom you have desired to see. ${ }^{34}$

A distinctive feature of this description is that the heavenly counterpart of Jacob, his «image», is engraved on a very special celestial entity, on the Throne of Glory. Engraving on the Throne might indicate an association with the Kavod since the Throne is the central part of the Kavod imagery - the seat of the anthropomorphic Glory of the Lord. The image engraved on the Throne might be an allusion to the face, ${ }^{35}$ the fiery face, since it is engraved on the fiery and glorious Throne of the Glory.

Besides the tradition of «engraving» on the Throne, some Jewish materials point to an even more radical identification of Jacob's image with Kavod. Jarl Fossum's research ${ }^{36}$ demonstrates that in some traditions about Jacob's image, his «image» or «likeness» is depicted not simply as engraved on the heavenly Throne, but as seated upon the Throne of Glory. ${ }^{37}$ Fossum argues that this second tradition is original. Christopher Rowland proposed that Jacob's image is «identical with the form of God on the throne of glory (Ezek. 1:26f.)». ${ }^{38} \mathrm{~J}$. Fossum offers additional support for this idea by pointing out

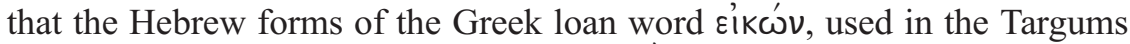

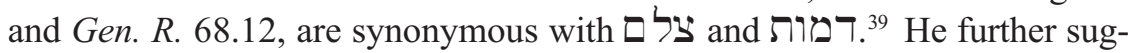

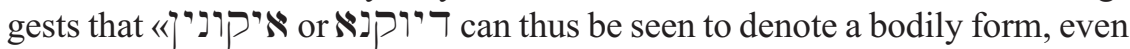
that of God, that is the Divine Glory».. ${ }^{40}$

The hypothesis about the identification of Jacob's image and the Divine Glory returns us again to the imagery of God's Kavod with which, as has been shown earlier, the Face in Ladder and 2 Enoch is closely associated.

${ }^{34}$ Targum Pseudo-Jonathan: Genesis... 99-100; Biblia Polyglotta Matritensia. IV. Targum Palaestinense in Pentateuchum... Vol. 1. 195.

${ }^{35}$ Hekhalot Rabbati (Synopse § 164) attests to the tradition of Jacob's face en-

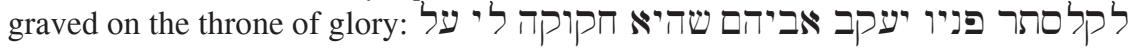
כםזי כבודי; see P. SchäFER, with M. SchlÜter and H. G. von Mutius, Synopse zur Hekhalot-Literatur (Tübingen, 1981) (TSAJ, 2) 72.

${ }^{36}$ Fossum, The Image of the Invisible God... 140-141.

${ }^{37}$ Fossum notes that this tradition is already observable in some versions of the Fragmentary Targum which do not contain the verb «engraved» or «fixed» (Fossum, The Image of the Invisible God... 141). He also points to a certain baraita (b. Hul. 91b) that seems to attests to the same tradition (139-140).

${ }^{38}$ C. Rowland, John 1:51, Jewish Apocalyptic and Targumic Tradition // NTS 30 (1984) 498-507 (504).

${ }^{39}$ Fossum, The Image of the Invisible God... 142.

${ }^{40}$ Ibid. 
Enochic materials may also correlate the Face of God (divine Kavod) with the heavenly counterpart of the visionary. In 2 Enoch, the Face of the Lord seems to play an important role in the description of Enoch's heavenly counterpart. 2 Enoch 39:3-6 depicts the patriarch who, during his short trip to the earth, retells to his children his earlier encounter with the Face. Enoch relates:

You, my children, you see my face, a human being created just like yourselves; I am one who has seen the face of the Lord, like iron made burning hot by a fire, emitting sparks. For you gaze into my eyes, a human being created just like yourselves; but I have gazed into the eyes of the Lord, like the rays of the shining sun and terrifying the eyes of a human being. You, my children, you see my right hand beckoning you, a human being created identical to yourselves; but I have seen the right hand of the Lord, beckoning me, who fills heaven. You see the extent of my body, the same as your own; but I have seen the extent of the Lord, without measure and without analogy, who has no end. ${ }^{41}$

Enoch's description provides a series of analogies in which the earthly Enoch compares his face and parts of his body with the attributes of the Lord's Face and body. For this investigation, however, another juxtaposition is most pertinent. It is a contrast between the two identities of the visionary: the earthly Enoch («a human being created just like yourselves») and his heavenly counterpart («the one who has seen the Face of God»). It appears that Enoch tries to describe himself in two different modes of existence: as a human being who now stands before his children with a human face and body and as the one who has seen God's Face in the celestial realm. These descriptions of two conditions (earthly and celestial) occur repeatedly in tandem. It is possible that the purpose of Enoch's instruction to his children is not to stress the difference between his human body and the Lord's body, but to emphasize the distinction between this Enoch, a human being «created just like yourselves», and the other angelic Enoch who has been standing before the Lord's face. Enoch's previous transformation into the glorious one and his initiation into Sar ha-Panim in 2 En. 22.7 support this suggestion. It is unlikely that Enoch somehow completely abandoned his supra-angelic status and his unique place before the Face of the Lord granted to him in the previous chapters. An account of Enoch's permanent installation can be found in chapter 36 where the Lord tells Enoch, before his short visit to the earth, that a place has been prepared for him and that he will be in the front of Lord's face «from now and forever». ${ }^{42}$ Finally, in chapter $43,{ }^{43}$ Enoch introduces himself to his children

${ }^{41}$ Andersen, 2 Enoch... 163.

422 Enoch 36:3. Andersen, 2 Enoch... 161.

${ }^{43}$ A similar testimony can also be found in the passage of 2 Enoch preserved in the Slavonic collection of ethical writings, «The Just Balance» (Мерило Праведное), 
as the Governor ${ }^{44}$ of the World. ${ }^{45}$ This title gives additional proof for the fact that the permanent installation of Enoch-Metatron in the heavenly offices, including the office of the Prince of the World (שר העולם), has already taken place. The importance of this account for the idea of the heavenly counterpart in 2 Enoch is apparent because it points to the simultaneous existence of Enoch's angelic double installed in heaven and its human counterpart, whom God sends periodically on missionary errands. Targumic and rabbinic Jacob accounts also attest to this view of the heavenly counterpart when they depict angels beholding Jacob as one who at one and the same time is installed in heaven and is sleeping on earth. ${ }^{46}$

The idea about the heavenly counterpart of the visionary found in 2 Enoch is also present in another early Enochic account. One of the booklets of 1 (Ethiopic) Enoch attests a similar tradition. Scholars have previously observed $^{47}$ that the Similitudes seem to entertain the idea of the heavenly twin of a visionary when it identifies Enoch with the Son of Man. ${ }^{48}$ For a long time, students of the Enochic traditions were puzzled by the fact that the Son of Man, who in previous chapters of the Similitudes has been distinguished from Enoch, becomes suddenly identified in 1 Enoch 71 with the patriarch. James VanderKam suggests that this puzzle can be explained by the Jewish

in which the existence of 2 Enoch was first made public. Cf. М. Н. Тихомиров, Мерило Праведное по рукописи XIV века (Москва, 1961).

${ }^{44}$ Andersen translates the title as «the manager of the arrangements on earth», see ANDERSEN, 2 Enoch... 217.

${ }^{45}$ On this title of Enoch and its connection with the office of the Prince of the World, see A. OrLov, Titles of Enoch-Metatron in 2 Enoch // JSP 18 (1998) 82-85.

${ }^{46}$ Targ. Neof. to Gen 28:12: «...and behold, the angels from before the Lord ascended and descended and observed him [Jacob]» (Targum Neofiti 1: Genesis... 140); Gen. $R$. 68.12: «...they ascended on high and saw his features and they descended below and found him sleeping» (Midrash Rabbah... Vol. 2. 626).

${ }^{47}$ See J. VanderKam, Righteous One, Messiah, Chosen One, and Son of Man in 1 Enoch 37-71 // The Messiah: Developments in Earliest Judaism and Christianity. The First Princeton Symposium on Judaism and Christian Origins / Ed. J. H. CharLESWORTH et al. (Minneapolis, 1992) 161-191 (182-183); M. A. KnIBB, Messianism in the Pseudepigrapha in the Light of the Scrolls // DSD 2 (1995) 177-180; Fossum, The Image of the Invisible God... 144-145; C. H. T. Fletcher-Louis, Luke-Acts: Angels, Christology and Soteriology (Tübingen, 1997) (WUNT, 2/94) 151.

${ }^{48}$ It is important to note that in the Similitudes, the Son of Man is depicted as seated on the Throne of Glory. See 1 En. 62:5; 69:29. Fossum observes that «in the "Similitudes" the "Elect One" or "Son of Man" who identified as the patriarch Enoch, is enthroned upon the "throne of glory". If "glory" does not qualify the throne but its occupant, Enoch is actually identified with the Glory of God». Fossum further concludes that «...the "Similitudes of Enoch" present an early parallel to the targumic description of Jacob being seated upon the "throne of glory"» (Fossum, The Image of the Invisible God... 145). 
notion, attested in several ancient Jewish texts, that a creature of flesh and blood could have a heavenly double or counterpart. ${ }^{49}$ To provide an example, VanderKam points to Jacob's traditions in which the patriarch's «features are engraved on high». ${ }^{50} \mathrm{He}$ stresses that this theme of the visionary's ignorance of his higher angelic identity is observable, for example, in the Prayer of Joseph.

It is noteworthy that in the Similitudes, similarly in 2 Enoch and Ladder, ${ }^{51}$ the theme of the heavenly counterpart seems to conflate with the imagery of God's Kavod. 1 Enoch 71:5 reports that Enoch is brought by Michael to the fiery structure, surrounded by the rivers of living fire, which he describes as «a something built of crystal stones, and in the middle of those stones tongues of living fire» ${ }^{52}$

There is no doubt that the fiery «structure» in the Similitudes represents the Throne of Glory, which, in another booklet of 1 Enoch, is also described as the crystal structure issuing streams of fire..$^{53}$ An explicit reference to the Throne of Glory in $1 E n .71: 8,{ }^{54}$ immediately after the description of the fiery «crystal» structure, makes this clear.

Similarities between 1 Enoch 71 and 2 Enoch 22 in the depictions of $\mathrm{Ka}$ vod and Enoch's transformation near the Throne of Glory are also apparent.

a. In both accounts ( 1 En. 71:3-5 and 2 En. 22:6), Enoch is brought to the Throne by archangel Michael.

b. Angelology of the Throne in 1 Enoch, as in 2 Enoch and Ladder, ${ }^{55}$ includes three classes of angelic beings: ophanim, cherubim and seraphim.

${ }^{49}$ VANDERKam, Righteous One, Messiah, Chosen One, and Son of Man... 182183.

${ }^{50}$ Ibid.

${ }^{51}$ A notable detail in the description is that during his ascension Enoch, in a manner similar to Jacob's vision of the ladder, sees the angelic «movements» and the angelic «faces». In $1 \mathrm{En}$. 71:1 he reports about «...the sons of the holy angels treading upon flames of fire, and their garments (were) white, and their clothing, and the light of their face (was) like snow» (KNIBB, The Ethiopic Book of Enoch... Vol. 2. 165).

${ }^{52}$ KNIBB, The Ethiopic Book of Enoch... Vol. 2. 166.

${ }^{53}$ In the Book of the Watchers 14:18-19 the Throne of Glory is also described as a crystal structure surrounded of the rivers of fire. The reference to «crystal»structure also recalls the depiction of the Throne in Ezek. 1.26, where it is described as a throne of sapphire (ספיר).

${ }^{54} 1$ En. 71:7: «And round about (were) the Seraphim, and the Cherubim, and the Ophannim; these are they who do not sleep, but keep watch over the throne of his glory» (KNIBB, The Ethiopic Book of Enoch... Vol. 2. 166).

55 The Ladder also refers to three classes of angels, ophanim (many-eyed ones), cherubim and seraphim, right after the remark about the Throne: «...the fiery Throne of Glory ... and the many-eyed (ones) just I saw in my dream, holding the four-faced cherubim, bearing also the many-eyed seraphim» (LUNT, Ladder of Jacob... 408). 
c. Both Enochic accounts speak about the transformation of the visionary. Enoch's metamorphosis in 1 Enoch 71 recalls the description of the luminous transformation of Enoch into a glorious heavenly being from $2 \mathrm{En}$. $22: 8-9$.

d. In both cases, the transformation takes place in front of the fiery «structure», a possible source of both transformations.

e. Studies in the past have noted that in both accounts the transformation of the visionary takes place in the context of the angelic liturgy (2 En. $21: 1-22.10 ; 1$ En. $71: 11-12) .{ }^{56}$ The same feature is also observable in Ladder 2.15-18.

f. In both accounts Enoch falls on his face before the Throne. ${ }^{57}$

g. The manner in which Enoch is greeted near the Throne of Glory in 1 En. 71:14-17 evokes the scene from 2 En. 22:5-6, where the Lord personally greets Enoch. In both accounts we have an address in which the visionary is informed about his «eternal» status. ${ }^{58}$

These features of both Enochic accounts, entertaining the idea of the heavenly twin, point to the importance of the vision of the Kavod in the process of acquiring knowledge about the heavenly counterparts of the visionaries. It is not coincidental that in Jacob's tradition, which also attests the idea of the heavenly counterpart, the vision of God's glory also becomes an important theophanic motif. It is clearly recognizable in the targumic Jacob's accounts and the Ladder, where reports about Jacob's angelic counterpart are creatively conflated with theophanic traditions about the vision of God's Kavod.

\section{Uriel-Sariel-Phanuel}

Another prominent trait that links Jacob's account in the Ladder with both above mentioned Enochic accounts ( $1 \mathrm{En} .71$ and $2 \mathrm{En}$. 22) is the reference to the angel Sariel, also known in various traditions under the names of Phanuel and Uriel..$^{59}$

${ }^{56}$ Fletcher-Louis, Luke-Acts... 154.

${ }^{57} 1$ En. 71:11: «And I fell upon my face» (KNIBB, The Ethiopic Book of Enoch... Vol. 2. 166); 2 En. 21:2 : «I fell on my face» (ANDERSEN, 2 Enoch... 135).

${ }^{58} 1$ En. 71:14-15: «You are the Son of Man who was born to righteousness, and righteousness remains over you... and so you will have it for ever and for ever and ever» (KNIBB, The Ethiopic Book of Enoch... Vol. 2. 166-167); 2 En. 22:5-6: «Be brave, Enoch! Don't be frightened! Stand up, and stand in front of my face forever» (ANDERSEN, 2 Enoch... 138-139).

${ }^{59} \mathrm{~J}$. Smith observes that in five instances in 1 Enoch $(40: 9 ; 54: 6 ; 71: 8,9,13)$ confined to the Similitudes, Phanuel replaces Uriel in a catalog of the four archangels. He also points out that while Sariel is a relatively unknown angelic figure, his 
In 2 Enoch 22-23, Uriel $^{60}$ plays an important role during Enoch's initiations near the Throne of Glory. ${ }^{61} \mathrm{He}$ instructs Enoch about various subjects of esoteric knowledge in order to prepare him for various celestial offices, including the office of the Heavenly Scribe.

1 Enoch 71 also refers to the same angel and names him Phanuel. In the Similitudes, he occupies an important place among the four principal angels, namely, the place usually assigned to Uriel. In fact, the angelic name «Phanuel» might be a title which stresses the celestial status of Uriel/Sariel ${ }^{62}$ as one of the servants of the divine Panim. ${ }^{63}$

The title «Phanuel» is reminiscent of the terminology found in various Jacob's accounts. In Gen. 32:31, Jacob names the place (המקום) of his wrestling with God as Peniel (פניטא) - the Face of God. ${ }^{64}$ Scholars be-

name seems to be quite frequently conflated with Uriel, as in 1 En. 9:1. Cf. J. Z. SMiтh, Prayer of Joseph // OTP. Vol. 2. 699-714 (708-709). For the discussion about Uriel/ Sariel/Phanuel, see J. Greenfield, Prolegomenon // H. Odeberg, 3 Enoch or the Hebrew Book of Enoch (New York, 1973 [Cambridge, 1928]) xxxiv-xxxv; Lunt, The Ladder of Jacob... 405, n. 10; J. MiLik, The Books of Enoch: Aramaic Fragments of Qumran Cave 4 (Oxford, 1976) 170-174; Olyan, A Thousand Thousands Served Him... 105-109; J. Z. Sмітн, The Prayer of Joseph // Religions in Antiquity: Essays in Memory of Erwin Ramsdell Goodenough / Ed. J. Neusner (Leiden, 1968) (SHR, 14) 270 and 227; G. Vermes, The Archangel Sariel: A Targumic Parallel to the Dead Sea Scrolls // Christianity, Judaism and Other Greco-Roman Cults / Ed. J. Neusner (Leiden, 1975) (SJLA, 12.3) 159-166; G. Vermes, The Impact of the Dead Sea Scrolls on Jewish Studies during the Last Twenty-Five Years // JJS 26 (1975) 1-14 (13).

${ }^{60}$ Slav. Rеревеилъ (Vereveil).

${ }^{61}$ The beginning of this tradition can be found in the Book of Heavenly Luminaries (1 En. 74:2) where Enoch writes the instructions of the angel Uriel regarding the secrets of heavenly bodies and their movements. See KnIBB, The Ethiopic Book of Enoch... Vol. 2. 173.

${ }^{62}$ Vermes observes that at Qumran, «Sariel becomes one of the four chief angels, replacing Uriel, the traditional fourth archangel in the Greek Enoch and midrashic literature ... He also appears in an Aramaic fragment of 4Q Enoch 9.1» (VERMES, The Impact of the Dead Sea Scrolls on Jewish Studies... 13).

${ }^{63}$ Hekhalot Rabbati (Synopse $§ 108$ ) refers to the angel Suria/Suriel as the Prince of the Face: שוריאוסוריאי שר הפנים. Cf. SchÄfer, Schlüter, von Mutius, Synopse zur Hekhalot-Literatur... 52. On the identification of Sariel with the Prince of the Presence, see Odeberg, 3 Enoch... 99-100; SмIth, Prayer of Joseph... 709.

${ }^{64}$ The connection between the terms God's Face (פניטאל) and the Place (המקום) in Gen. 32:31 is important. In later theophanic contexts the term המקום is closely associated with the Kavod imagery. This tradition can be found, for example, in $3 \mathrm{En}$. 45:1; 47:1; 48D:8. 3 Enoch also uses an expression «the Curtain (pargod) of the Place» in reference to the celestial veil, which shields the angelic hosts from the harmful luminescence of the Kavod. 
lieve that the angelic name Phanuel and the place Peniel are etymologically connected. ${ }^{65}$

Although the Ladder's narrative does not directly refer to the angel named Phanuel, it uses another of his names, Sariel, in reference to the angelic being, who interprets Jacob's dream and announces to him his new angelic status, depicted symbolically in the changing of the patriarch's name to Israel. The Ladder of Jacob 2 portrays Jacob asking God in prayer for help in interpreting the dream. Chapter 3 of the Ladder relates that God responds to Jacob's prayer by commanding: «Sariel, leader of those who comfort, you who in charge of dreams, go and make Jacob understand the meaning of the dream». The text further depicts the angelophany of Sariel who comes to the patriarch to inform him about his new angelic name and status.

This reference to Sariel/Uriel as the angel who instructs/wrestles with Jacob and announces to him his new angelic name is documented in several other sources, including Targum Neofiti and the Prayer of Joseph. In the Prayer of Joseph, Jacob attests that «Uriel, the angel of God, came forth and said that "I [Jacob-Israel] had descended to earth and I had tabernacled among men and that I had been called by the name of Jacob". He envied me and fought with me and wrestled with me...». ${ }^{66}$

In targumic and rabbinic accounts, Sariel/Uriel is also depicted as the angel who wrestled with Jacob and announced him his new angelic name.

Targum Neofiti to Gen. 32.25-31 reads:

And Jacob was left alone; and the angel Sariel (שריאל) wrestled with him in the appearance of a man and he embraced him until the time the dawn arose. When he saw that he could not prevail against him, he touched the hollow of his thigh and the hollow of Jacob's thigh became benumbed in his wrestling with him. And he said: «Let me go because the rise of the dawn has arrived, and because the time of the angels on high to praise has arrived, and I am a chief of those who praise» (ואנא ריש למשבחיאו). And he said: «I will not let you go unless you bless me». And he said to him: «What is your name?» And he said: «Jacob». And he said: «Your name shall no longer be called Jacob but Israel, because you have claimed

${ }^{65} \mathrm{G}$. Vermes suggests that the angelic name Phanuel «is depended on the Peniel/ Penuel of Genesis 32». Cf. Vermes, The Impact of the Dead Sea Scrolls on Jewish Studies... 13. Smith supports Vermes' position. In his opinion, «it is most likely that the name Phanuel is to be derived from the place name Peniel/Penuel (the face of God) in Genesis 32:30, and therefore may be related to the title "a man seeing God"» (Sмiтн, Prayer of Joseph... 709). See also S. Olyan, who argues that «the angel Penuel was either derived from texts such Exod. 13:14-15 and Deut. 4:37, where the divine presence is given figurative treatment, or it emerged from the exegesis of Gen. 32:25-33» (Olyan, A Thousand Thousands Served Him... 108-109).

${ }^{66} \mathrm{~S}$ мiтн, Prayer of Joseph... 713. 
superiority with angels from before the Lord and with men and you have prevailed against them. And Jacob asked and said: «Tell me your name I pray»; and he said: «Why, now, do you ask my name?» And he blessed him there. And Jacob called the name of the place Peniel (כניאל) because: «I have seen angels from before the Lord face to face and my life has been spared». ${ }^{67}$

Scholars have previously noted that «in the circles represented by the Similitudes of Enoch, Qumran and Neofiti variety of the Palestinian Targum, the angelic adversary of Jacob was recognized as one of the four celestial princes and called alternatively Sariel or Phanuel». ${ }^{68}$ It appears that the Ladder also belongs to the same circles. In Targ. Neof. and Frag. Targ. ${ }^{69}$ to Gen 32:27, Sariel is defined as «the chief of those who give praise» (שי ר

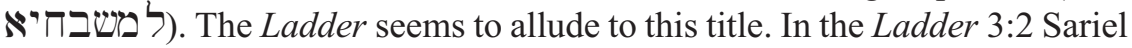
is described as «stareishino uslazhdaemych» ${ }^{70}$ which can be translated as «the chief of those who give joy». ${ }^{71}$

It is of interest to note that in the Ladder, Sariel/Phanuel imagery seems to be influenced by the Enochic tradition even more extensively than in the Targums; in the Ladder, the motif of wrestling is completely absent and is replaced by the depiction of Sariel as the interpreter of dreams. It seems that Sariel/Uriel in the Ladder assumes the traditional «Enochic» functions of angelus interpres. ${ }^{72}$

\section{Princes of the Face}

In the Ladder and the Prayer of Joseph, Jacob's identification with his heavenly counterpart, the angel Israel, involves the initiatory encounter with the angel Sariel/Uriel, who in other texts is also known as Phanuel, the angel of the Divine Presence or the Face. The same state of events is observable in

${ }^{67}$ Targum Neofiti 1: Genesis... 158; A. DíEz MAcho, Neophyti 1, Targum Palistinense Ms de la Biblioteca Vaticana. 6 vols (Madrid-Barcelona, 1968) (Textos y Estudios, 7) Vol. 1. 217-219.

${ }^{68}$ Vermes, The Impact of the Dead Sea Scrolls on Jewish Studies... 13; SMIth, Prayer of Joseph... 709.

${ }^{69}$ KLEIN, The Fragment-Targums of the Pentateuch... Vol. 1. 59; Vol. 2. 22.

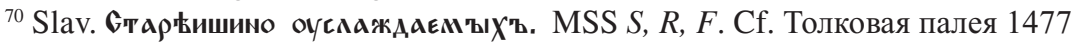
года... 101b; КушЕЛЕВ-БЕзБоРодко, Памятники старинной русской литературы... Т. 3. 28; ФРАнКО, АПокріфи і легенди... Т. 1. 110.

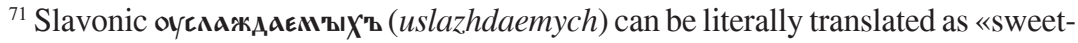
ened». Cf. Старославянский словарь по рукописям X-XI веков / Ред. Р. М. ЦЕйтлин (Москва, 1994) 477; И. И. СРЕзнЕвский, Словарь древнерусского языка. 3 тт. (Москва, 1989) Т. 3. 1266.

${ }^{72} \mathrm{On}$ Uriel as an angelus interpres, see C. A. GIESCHEN, Angelomorphic Christology: Antecedents and Early Evidence (Leiden, 1998) (AGJU, 42) 60. 
Enochic materials where Uriel serves as a principal heavenly guide to another prominent visionary who has also acquired knowledge about his own heavenly counterpart, namely, Enoch/Metatron. In both traditions, Uriel/Sariel/ Phanuel appears as the guide who assists the visionaries in acquiring or identifying with their new celestial identities.

The process of establishing twinship with the heavenly counterpart might be reflected in the initiatory procedure of becoming a Sar ha-Panim, one of the angelic ${ }^{73}$ Princes of the Divine Face or Presence, the prominent celestial office, which is often described in detail in various apocalyptic and Merkabah accounts. The installation of a visionary as Sar ha-Panim seems to correlate with the procedure of identifying a visionary with his heavenly counterpart. ${ }^{74}$ In 1 Enoch 71, Enoch is transformed and identified with the Son of Man in front of God's Throne. In 2 En. 22:6-10, Enoch's initiation into one of the Princes of Presence ${ }^{75}$ also takes place in front of the fiery Face of the Lord. This encounter transforms Enoch into a glorious being. It is important to note that after this procedure Enoch observes that he had become like one of the glorious ones, and there was no observable difference. ${ }^{76}$ The last phrase describes Enoch's transition to his new identity as «one of the glorious ones». This identity might refer to his angelic counterpart. It also indicates that Enoch's earthly appearance/face has been radically altered and that the visionary has now acquired a new «face» which «mirrors» or «doubles» the Face of the Lord. ${ }^{77}$ The motif of engraving the image of the visionary on the Throne

${ }^{73}$ For a complete discussion about angels as the heavenly counterparts of humans, see De Conick, Seek to See Him... 148-157.

${ }^{74}$ The reference to the angels of the Presence as the heavenly counterparts of humans is not confined solely to the Jewish pseudepigrapha. April De Conick's research refers to several important Christian passages in which angels of the Presence/ the Face serve as heavenly counterparts of humans; see De ConICK, Seek to See Him... 153-154. One of such traditions is reflected in Mt.18:10: «See that you do not despise one of these little ones; for I tell you that in heaven their angels always behold the face of my Father who is in heaven».

75 On Enoch's role as the Prince of the Presence in 2 Enoch, see OrLOv, Titles of Enoch-Metatron in 2 Enoch... 74-75.

${ }^{76}$ Andersen, 2 Enoch... 139.

77 A visionary, therefore, becomes a reflection or even a «representation» of the Face/Kavod, a sort of its vice-regent. Christopher Morray-Jones observes that «there is evidence, then, of the early existence of a tradition concerning the ascent to heaven of an exceptionally righteous man who beholds the vision of the divine Kabod upon Merkabah, is transformed into an angelic being and enthroned as celestial vice-regent, thereby becoming identified with the Name-bearing angel who either is or is closely associated with the Kabod itself and functions as a second, intermediary power in heaven» (C. R. A. Morray-Jones, Transformational Mysticism in the ApocalypticMerkabah Tradition // JJS 43 (1992) 10-11). 
might also serve as a metaphor for the similarity between the visionary's face and the Face. There is no doubt that one of the features which unifies both «faces» is their luminosity.

2 Enoch's narrative gives evidence that Enoch's face acquired the same qualities of luminosity as the Face of the Lord. In 2 Enoch 37, the Lord calls one of his angels to chill the face of Enoch before his return to earth. The angel, who «appeared frigid», then chilled Enoch's face with his icy hands. Immediately after this procedure, the Lord tells Enoch that if his face had not been chilled in such a way, no human being would be able to look at his face. This chilling procedure indicates that Enoch's metamorphosis near the Face into the Sar ha-Panim involves the transformation of the visionary's face into the fiery, perilous entity which now resembles Kavod. We can find a detailed description of this process in another «Enochic» text, Sefer Hekhalot, which describes the transformation of Enoch/Metatron, the Prince of the Divine Presence, into the fiery creature:

R. Ishmael said: The angel Metatron, Prince of the Divine Presence, the glory of highest heaven, said to me: When the Holy One, blessed be he, took me to serve the throne of glory, the wheels of the chariot and all needs of the Shekinah, at once my flesh turned to flame, my sinews to blazing fire, my bones to juniper coals, my eyelashes to lightning flashes, my eyeballs to fiery torches, the hairs of my head to hot flames, all my limbs to wings of burning fire, and the substance of my body to blazing fire. ${ }^{78}$

It is possible that the reference to the heavenly counterpart of Jacob in the form of his image (engraved) on the Throne of Glory also implies that Jacob is one of the servants of the Divine Face. This possibility is already hinted at in the biblical account where Jacob is attested as one who saw God face to face. ${ }^{79}$ Moreover, in some of Jacob's traditions, he is directly described (in a manner similar to Enoch/Metatron) as the Prince of the Divine Face. We learn about this title from the Prayer of Joseph $8,{ }^{80}$ where Jacob-Israel himself unveils his status as the Sar $^{81}$ ha-Panim, ${ }^{82}$ proclaiming that he is «the first minister before the Face of God».

${ }^{78} 3$ En. 15:1. AleXANDER, 3 Enoch... 267.

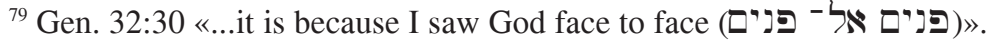

${ }^{80}$ The tradition about Jacob as the Prince of Presence seems to be also reflected in Targ. Onq. to Gen. 32:29: "Whereupon, he said, "No longer shall your name be called Jacob, but rather Israel; for your are a prince before the Lord and among men; therefore have you prevailed"» (The Targum Onqelos to Genesis... 116).

${ }^{81}$ Vermes notices that Targum Neofiti explains the etymology of Israel from שרר («to rule, to act as a prince»); see Vermes, The Impact of the Dead Sea Scrolls on Jewish Studies... 13.

${ }^{82}$ Gieschen, Angelomorphic Christology... 141-142. 
It is also not coincidental that the initiation of Jacob into an angelic being involves another servant of the Face, the angel Sariel whose last name, Phanuel, ${ }^{83}$ reflects his close proximity to the Face of God. As has been mentioned previously, this initiatory pattern is already observable in the Enochic tradition, where Sariel/Uriel/Phanuel (along with another angel of the Presence, Michael ${ }^{84}$ ) actively participates in the initiation of the another prominent servant of the Divine Face, Enoch/Metatron.

However, Jacob's identification with a Sar ha-Panim seems to be missing one detail that constitutes a distinct feature of the descriptions of visionaries initiated in this office, that is the luminous metamorphosis of an adept's face and body. The Ladder of Jacob and Prayer of Joseph, as well as the biblical account of Jacob's vision, are silent about any transformation of Jacob's body and his face. This tradition, however, can be found in another prominent account connected with the Jacob story. ${ }^{85}$ In this important material, the eyes of Jacob, similar to the eyes of the transformed Metatron, are emitting flashes of lighting.

\section{Conclusion}

Finally, it is necessary to address the question why some theophanic traditions depict angelic beings as both the servants of the Face and the Face itself. Later Merkabah accounts categorize Metatron as the Face of God. ${ }^{86}$

${ }^{83}$ The fact that Sariel/Uriel/Phanuel is known under several names might indicate that this angel also serves as a heavenly counterpart in the manner similar to other servants of the Face such as Jacob-Israel, Enoch/Metatron, and possibly Melchizedek/Michael. On the identification of Michael with Melchizedek, see J. R. DAVILA, Melchizedek, Michael, and War in Heaven // SBLSP 35 (1996) 259-272; D. D. HANNAH, Michael and Christ: Michael Traditions and Angel Christology in Early Christianity (Tübingen, 1999) (WUNT, 2/109) 70-74.

${ }^{84}$ Olyan refers to Rashi's passage which identifies «the 'angel of his presence' of Isa. 63:9 with Michael, the Prince of Presence» (OLYAN, A Thousand Thousands Served Him... 108).

${ }^{85}$ The beginning of the second half of Joseph and Aseneth gives a description of Joseph and Aseneth visiting Jacob. Jos. and Asen. 22:7-8 says that when Aseneth saw Jacob, she «was amazed at his beauty... his eyes (were) flashing and darting (flashes of) lighting, and his sinews and his shoulders and his arms were like (those) of an angel, and his thighs and his calves and his feet like (those) of a giant. And Jacob was like a man who had wrestled with God. And Aseneth saw him and was amazed, and prostrated herself before him face down to the ground» (C. BURCHARD, Joseph and Aseneth // OTP. Vol. 2. 177-247 (238)).

${ }^{86}$ For the identification of Metatron with the Face, see DE ConICK, Heavenly Temple Traditions and Valentinian Worship... 329; D. J. HALPERIN, The Faces of the Chariot (Tübingen, 1988) (TSAJ, 16) 424-425. Morray-Jones notes that in the Merkabah texts Metatron «in some sense embodies, the Kabod». MorRAY-JonEs, Transformation Mysticism in the Apocalyptic-Merkabah Tradition... 9. 
The reference to Uriel/Sariel, who is also known as Phanuel («the Face of God»), can serve as another example. This ambiguity in the theophanic tradition is also apparent in the Slavonic Ladder of Jacob, where the fiery Face can be taken as either God's Kavod or an enthroned vice-regent associated with the Face (i.e. the enthroned Jacob-Israel). The difficulty in discerning between these two luminous entities can be illustrated through a reference to a late «Enochic» passage ( $3 \mathrm{En}$.), describing the enthronement of Metatron at the door of the seventh palace. From this account we learn that when one infamous visionary encountered the enthroned Metatron, he took it as something equal to the Chariot. Then, according to the story, the visionary opened his mouth and uttered: «There are indeed two powers ${ }^{87}$ in heaven!» ${ }^{88}$

Besides other things, this account might serve as:

1. an additional evidence that some heavenly counterparts are indeed «mirrors» of the Face;

2. an important lesson about the evasive nature of the celestial «faces»; and

3. a warning about the possible perils for those who try to explain what these «faces» might really represent.

\begin{abstract}
The study investigates the imagery of the heavenly counterpart of the visionary found in the Slavonic Ladder of Jacob. The text describes Jacob's dream in which the patriarch sees the celestial «Face» as the fiery anthropomorphic extent, which serves as the embodiment of the Deity. This fiery extent, labeled in some biblical and intertestamental texts as the «Face», is related to the glorious celestial entity known in theophanic traditions as God's Kavod. It appears that in the Ladder of Jacob the fiery Face not only embodies God's Glory but also seems to represent the heavenly counterpart of Jacob. The bust of fire, labeled in the Ladder as the Face, can be associated with the heavenly «image» of Jacob engraved on the Throne of Glory. The traditions about the heavenly «image» of Jacob found in the Slavonic Ladder of Jacob demonstrate some similarities to the traditions found in several targumic texts which entertain the idea of the heavenly twin of Jacob.
\end{abstract}

${ }^{87}$ On «two powers in heaven», see Alan SEGAL's pioneering research in his Two Powers in Heaven: Early Rabbinic Reports about Christianity and Gnosticism (Leiden, 1977) (SJLA, 25).

${ }^{88}$ AleXANDER, 3 Enoch... 268. 